\title{
TRADUÇÃO INTERSEMIÓTICA COMO FATOR DE PRODUÇÃO DE LEGENDAS MEDIANTE PROCESSAMENTO DIGITAL DE IMAGENS E NARRATIVA FÍLMICA
}

\section{INTERSEMIOTIC TRANSLATION AS A FACTOR IN SUBTITLING PRODUCTION THROUGH DIGITAL IMAGE PROCESSING AND FILMIC NARRATIVE}

\begin{abstract}
Pedro Henrique de Paiva
GAUDENCIO

Universidade Federal de Campina Grande

Centro de Humanidades

Unidade Acadêmica de Letras

Campina Grande, Paraíba, Brasil. orcid.org/0000-0002-2260-7546

pedrohpgaudencio@gmail.com
\end{abstract}

\author{
Sinara de Oliveira BRANCO \\ Universidade Federal de Campina \\ Grande \\ Centro de Humanidades \\ Unidade Acadêmica de Letras \\ Campina Grande, Paraíba, Brasil. \\ orcid.org/0000-0003-2739-2254 \\ sinarabranco@gmail.com
}

\author{
Luciana Ribeiro VELOSO \\ Universidade Federal de Campina \\ Grande \\ Centro de Engenharia Elétrica e \\ Informática \\ Departamento de Engenharia Elétrica \\ Campina Grande, Paraíba, Brasil. \\ orcid.org/0000-0001-7564-1038 \\ luciana.veloso@dee.ufcg.edu.br
}

Resumo: Este artigo objetiva aplicar o processamento digital de imagens e tecnologia da informação para a análise de expressões faciais de personagens de filmes, como fator de influência na seleção de linguagem verbal a ser aplicada em legendas. Partindo de um corpus de cenas selecionadas a partir dos filmes Magnólia (1999) e Bicho de Sete Cabeças (2001), visamos: (i) analisar a construção das personagens nas narrativas fílmicas, aplicando técnicas de processamento digital de imagens; e (ii) explorar recursos da tecnologia da informação e do processamento digital de imagens, associados à Tradução Intersemiótica, para a análise de imagens e construção ou omissão de legendas, dando espaço à linguagem não verbal em momentos específicos da narrativa fílmica. Para tanto, as cenas selecionadas foram examinadas através da triangulação de dados obtidos pelo processamento digital de imagens via software de reconhecimento facial e quantificação emocional (Affectiva, EMOVIE); da análise das personagens inseridas em suas narrativas fílmicas (GAUDREAULT; JOST, 2009); e das escolhas tradutórias para a legendagem (DÍAZ CINTAS; REMAEL, 2014); considerando-se ainda a Tradução Intersemiótica como significação analógica entre sistemas de signos distintos (PLAZA, 2003). Constatamos que as reduções textuais impostas à legenda pelo meio audiovisual não afetam negativamente a compreensão espectatorial, dada a sua inserção nas obras através do conceito de coesão semiótica (DÍAZ CINTAS; REMAEL, 2014). Constatamos, também, que a face humana e as expressões faciais são relevantes à narrativa fílmica enquanto sistemas sígnicos complexos (EKMAN; FRIESEN, 2003) e que o processamento digital de imagens e a quantificação emocional, apesar da limitação para lidar com o contexto fílmico, apresentam novas possibilidades tecnológicas de utilização de software em prol da legendagem e do espectador. Palavras-chave: Tradução intersemiótica. Narrativa fílmica. Processamento digital de imagens. Legendagem. Expressões faciais.

\begin{abstract}
This paper aims to apply digital image processing and information technology to analyze facial expressions of movie characters as an influential factor for the selection of verbal language in subtitling. The corpus used in the study is comprised of scenes selected from the films Magnolia (1999) and Bicho de Sete Cabeças (2001) aiming at: 1) analyzing character construction in filmic narratives through the application of digital image processing techniques, and 2) exploring information technology and digital image processing resources associated with Intersemiotic Translation to analyze images and the construction or omission of subtitles, considering non-verbal language in specific moments of the filmic narrative. To this end, the selected
\end{abstract}


scenes were analyzed building on: triangulation of data obtained through digital image processing via software for facial recognition and emotional quantification (Affectiva, EMOVIE); the analysis of characters inserted in their filmic narratives (GAUDREAULT; JOST, 2009); and the translation choices for subtitles (DÍAZ CINTAS; REMAEL, 2014), considering Intersemiotic Translation as analogic signifying through distinct sign systems (PLAZA, 2003). Results showed that the textual reduction imposed to subtitles does not jeopardize spectatorial comprehension due to their insertion in audiovisual works through the concept of semiotic cohesion (DÍAZ CINTAS; REMAEL, 2014). They also showed that: 1) the human face and facial expressions are relevant in the filmic narrative as complex sign systems (EKMAN; FRIESEN, 2003), and 2) digital image processing and emotional quantification, albeit limited for dealing with filmic context, reveals new possibilities of technological use of software in favor of subtitling and the spectator.

Keywords: Intersemiotic translation. Filmic narrative. Digital Image processing. Subtitling. Facial expressions.

\section{Introdução}

onsiderando a relevância do processamento digital de imagens, bem como os
avanços na área da computação afetiva, justificados pelo interesse na pesquisa em
tais áreas em nível nacional (SOUSA et al., 2016a, 2016b; LEÃO et al., 2012; ANDRADE et al., 2013; DEMOS, 2011), lidamos com a aplicação de tecnologias como auxílio para a construção de legendas. Dessa forma, buscamos inovar e impactar a pesquisa na área dos Estudos da Tradução, mediante a aplicação de recursos da Ciência da Computação, buscando a cooperação entre áreas diversas - neste caso, entre professores-pesquisadores e estudantes dos Centros de Humanidades e de Engenharia Elétrica e Informática da Universidade Federal de Campina Grande.

Foi aplicado o processamento digital de imagens e tecnologia da informação para a análise de expressões faciais de personagens de filmes como fator de influência na seleção da linguagem verbal a ser usada em legendas, objetivando: (i) analisar a construção das personagens nas narrativas fílmicas, aplicando técnicas de processamento digital de imagens; e (ii) explorar recursos da tecnologia da informação e do processamento digital de imagens, associados à Tradução Intersemiótica, para a análise de imagens e para a construção ou omissão de legendas, dando espaço à linguagem não verbal em momentos específicos da narrativa fílmica. $\mathrm{O}$ corpus da pesquisa consiste em cenas selecionadas a partir de dois filmes: Magnólia (1999) e Bicho de Sete Cabeças (2001). Para alcançar os objetivos, discutiram-se conceitos relacionados: (i) à Semiótica; (ii) à Legendagem como atividade de Tradução Audiovisual e de Tradução Intersemiótica; (iii) à Narrativa Fílmica; e (iv) às Expressões Faciais.

Iniciando com a Semiótica, Santaella (1983, p. 13) define linguagem como "todos os sistemas de produção de sentido aos quais o desenvolvimento dos meios de reprodução de 
linguagem propicia hoje uma enorme difusão". Nesse sentido, Peirce (2010, p. 46) fundamenta as bases de sua fenomenologia semiótica na onipresença do signo, definido como "aquilo que, sob certo aspecto ou modo, representa algo para alguém" e "dirige-se a alguém, isto é, cria, na mente dessa pessoa, um signo equivalente, ou talvez um signo mais desenvolvido". O autor enxerga o signo não apenas como a unidade essencial à comunicação humana, mas também como aquilo que garante cognoscibilidade aos fenômenos que nos rodeiam. Esses fenômenos só podem ser apreendidos a posteriori, através da mediação sintética dos signos. Desse modo, o próprio pensamento é composto por signos, que se traduzem, em sucessão infinita, em signos distintos.

Peirce (2010) classifica os signos em três tricotomias, de acordo com suas naturezas, caso sejam mera qualidade, existentes concretos ou leis gerais. Ou seja, o autor considera as relações que os signos estabelecem com seus Objetos (aquilo que representam) ou com seus Interpretantes (signos mentais criados a partir da apreensão do signo primário). A classificação quanto à relação que o signo estabelece com seu Objeto configura-se como a mais relevante para este estudo e divide os signos em três possíveis categorias: Ícone, Índice e Símbolo.

Para Peirce (2010, p. 52), "um Ícone é um signo que se refere ao objeto que denota apenas em virtude de seus caracteres próprios, caracteres que ele igualmente possui quer um tal objeto realmente exista ou não”. Nesse sentido, o Ícone significa por analogia, dispondo de características e essências próprias que remetem ao seu objeto, como, por exemplo, a fotografia de uma casa pode significar a casa através de suas qualidades semelhantes a outras casas. O Índice, por sua vez, "é um signo que se refere ao objeto que denota em virtude de ser realmente afetado por esse objeto", constituindo-se numa espécie de Ícone caracterizado não pela "mera semelhança com seu objeto, [...] mas sim sua efetiva modificação pelo objeto". É o caso, por exemplo, da fumaça, que pode significar fogo. Por fim, Símbolo "é um signo que se refere ao objeto que denota em virtude de uma lei, normalmente uma associação de ideias gerais que opera no sentido de fazer com que o Símbolo seja interpretado como se referindo àquele objeto", como no caso (da grande maioria) das palavras: "mulher" refere-se à ideia geral de uma mulher e o faz não por características intrínsecas ao signo, mas pelo acordo social da língua.

Seguindo as ideias de Peirce, Plaza (2003) argumenta que qualquer pensamento é uma tradução, por apresentar caráter de transmutação de signo em signo. Partindo desse conceito, que enxerga o pensamento como intersemiótico, Plaza defende uma das possibilidades de 
definição da Tradução Intersemiótica como pensamento em signos. De acordo com o autor, os signos realizam, em sua significação, dois movimentos: o movimento centrífugo, em que cada signo tende à tradução através de outros signos; e o movimento centrípeto, em que os signos remetem a si mesmos, tendendo a se aproximarem da iconicidade peirceana, representando qualidades ou sensações. Plaza (2003) defende a impossibilidade de se pensar a Tradução Intersemiótica sob a noção de fidelidade, dada a materialidade dos signos, que carregam em si próprios características dos meios em que são produzidos, bem como considerada a tendência do signo estético de buscar significar-se em si mesmo, distanciando-se de seu Objeto e cessando seu movimento centrífugo em direção à tradução. Sob tal perspectiva, a Tradução Intersemiótica acontece sob a forma de apropriação análoga, em que se busca a construção criativa de novos signos que representem a mensagem (ou qualidade) dos signos-fonte de maneira distinta, porém análoga.

A face humana enquadra-se, também, como um sistema complexo de signos. Ekman e Friesen (2003, p. 10, tradução nossa) reconhecem-na como um "sistema de sinais e mensagens múltiplas"1, por veicular informações diversas a respeito da pessoa observada. Em 204 primeiro lugar, sinais estáticos, como estrutura óssea e cor da pele, e de lenta transição, com rugas, adiposidade, dentre outros, oferecem informações biológicas e físicas a respeito de quem observamos, como seu sexo, idade e etnia. Os sinais rápidos, gerados a partir da ativação de grupos musculares específicos da face, como erguer as sobrancelhas ou abrir a boca, são responsáveis por transmitir informações culturalmente acordadas, por exemplo, o sentido de uma piscadela, ou, no caso de maior interesse ao estudo, podem se originar, involuntariamente, a partir de emoções sentidas pela pessoa observada - dando origem às expressões faciais.

Ekman e Friesen (2003), em pesquisa realizada envolvendo pessoas em diferentes partes do mundo, mapearam grupos musculares da face para identificar as seis emoções universalmente reconhecíveis por observadores humanos: Surpresa, Medo, Nojo, Raiva, Alegria e Tristeza. Esses grupos musculares da face são denominados pelos autores de Action Units. No software de processamento digital por nós utilizado, os grupos musculares são denominados de landmarks. Apesar de diferenças culturais entre os fatores que motivam e modulam a sua demonstração, certas configurações faciais são reconhecíveis ao redor do globo - um sorriso, por exemplo, é universalmente associado à alegria.

Considerando as emoções e sua relevância em narrativas fílmicas, essas se configuram como um sistema sígnico complexo. Gaudreault e Jost (2009) apontam tal natureza ao 
classificar a Narrativa Fílmica como dupla narrativa na qual, a todo momento, articulam-se som e imagem de forma a veicularem mensagens complexas ao espectador. Somam-se ainda questões de significação tipicamente cinematográficas, como cortes e enquadramentos, que dividem a narrativa fílmica em meganarração, efetuada pelo diretor através da manipulação da mostração em tela e da edição de vídeo; e em subnarração, pertencente ao universo diegético da obra fílmica e efetuada pelas próprias personagens.

A Legendagem, enquanto atividade tradutória, é definida por Díaz Cintas e Remael como:

uma prática tradutória que consiste na apresentação de um texto escrito, geralmente na parte inferior da tela, que busca recontar o diálogo original dos falantes, bem como os elementos discursivos aparentes na imagem (letras, grafite, inscrições, cartazes e similares) e informações contidas na trilha sonora (música, voice off). (DÍAZ CINTAS; REMAEL, 2014, p. 8, tradução nossa) ${ }^{2}$

Essa definição apresenta a legendagem como um processo complexo, no qual se encerra não somente a tradução de emissões verbais orais para sua forma escrita, mas no qual devem considerar-se a miríade de sistemas sígnicos presentes na obra audiovisual, inclusas, aqui, as expressões faciais, e no qual se encerram aspectos socioculturais tanto da população produtora do texto-fonte quanto da população receptora do texto-alvo (DÍAZ CINTAS; REMAEL, 2014), que devem ser levados em conta durante a tradução de forma a evitar perdas para o público espectador. Soma-se à tal complexidade a própria natureza do meio audiovisual, cujas características materiais são definidas pela fisicalidade da tela em que se exibem os textos. As legendas devem, necessariamente, figurar no texto audiovisual de forma a serem legíveis e acompanharem as emissões verbais às quais correspondem. Tais restrições implicam que o texto traduzido sofra reformulações a fim de ser reduzido. Para tanto, Díaz Cintas e Remael (2014) preveem diversas possibilidades de reconstrução textual na forma de reduções via transformações linguísticas (contrações, mudanças de classe sintática, tempo verbal, uso de pronomes, dentre outras) ou pela omissão de itens de baixa relevância.

Para que tais possibilidades possam ser analisadas, apresentamos, a seguir, a construção do corpus seguido de sua análise.

\section{Construção e Análise do Corpus}

Para a composição do corpus de análise, dois filmes foram selecionados: Magnólia (1999), dirigido por Paul Thomas Anderson, e Bicho de Sete Cabeças (2001), dirigido por 
Laís Bodanzky. Dada a natureza da pesquisa, que visa relacionar expressões faciais e narrativa fílmica, o primeiro fator de seleção para ambas as obras foram suas elevadas cargas emocionais. Considerando-se, também, que a linguagem cinematográfica é culturalmente situada (PEIRCE, 2010; PLAZA, 2003; SANTAELLA, 1983), prezamos pela seleção de duas obras produzidas em diferentes contextos, uma brasileira e outra estadunidense, buscando revelar que facilidades ou dificuldades podem emergir de suas peculiaridades.

Magnólia centra-se em temas de perda e trauma, acompanhando alguns dias na vida de diversas personagens. Construída como um mosaico, a obra nos apresenta recortes sob o ponto de vista de personagens aparentemente desconexas, mas que, gradativamente, mostramse interligadas, revelando o arco narrativo que as une. Bicho de Sete Cabeças, por sua vez, narra a história de Neto, um adolescente usuário de maconha que é forçosamente internado em um manicômio por seu pai, que acredita que seu filho seja viciado. Baseado no livro autobiográfico de Austregésilo Carrano (1957-2008), Canto dos Malditos (1990), o filme ilustra os abusos psicológicos e físicos sofridos por pacientes manicomiais no Brasil até o início dos anos 2000.

Após a escolha dos filmes a serem analisados, foi feita a seleção de cenas para processamento digital. Para tanto, diversos fatores foram observados. Em primeiro lugar, a utilização de um software de reconhecimento e quantificação de expressões faciais implica uma série de restrições materiais ao objeto de análise. Para que seja possível o reconhecimento das emoções faciais, os atores em cena devem encontrar-se em posição aproximada à frontal, devem ter seus rostos suficientemente iluminados e desimpedidos e, preferencialmente, devem ser enquadrados em close suficiente para que detalhes de suas expressões sejam visíveis, sem, contanto, que parte alguma da face (queixo, testa etc.) fique fora de quadro. A seleção levou em conta, também, fatores narrativos e tradutórios, de modo tal que as cenas, além de atenderem aos pré-requisitos impostos pelo software, deveriam demonstrar relevância diegética e/ou apresentar alguma característica de interesse no processo de legendagem, seja pela aproximação ou distanciamento dos pressupostos teóricos aqui adotados como referencial.

As cenas selecionadas foram extraídas dos DVDs de ambos os filmes através da utilização de dois softwares gratuitos: Bandicam e Bandicut, ambos desenvolvidos pela Bandicam Company. As imagens foram selecionadas a partir da utilização da Ferramenta de Captura de tela nativa do Windows 10, que permite selecionar e salvar itens mostrados na tela em arquivos .png. O software Bandicam (Figura 1) permite a gravação, em arquivo de vídeo 
ou imagem, de itens exibidos na tela do computador de modo tal que, a partir da reprodução em tempo real dos DVDs, foi possível criar arquivos de vídeo contendo, exclusivamente, as cenas a serem analisadas. O Bandicut (Figura 2), por sua vez, permite a edição de arquivos de vídeo por meio de recorte e colagem. Sua utilização aconteceu para o refinamento das cenas selecionadas e capturadas mediante uso do Bandicam, reduzindo seu tempo total através da eliminação de trechos que não atendessem às especificações impostas pelo processamento digital.

Figura 1 - Tela inicial do Bandicam

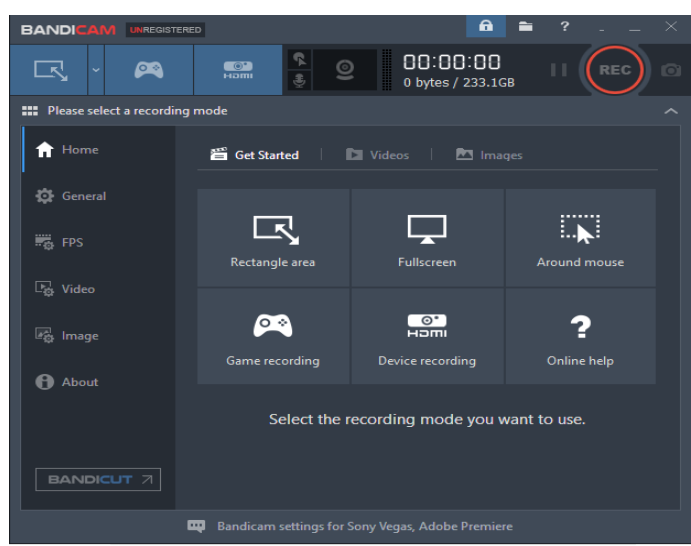

Fonte: BANDICAM Screen Recorder (2018).

Figura 2 - Tela inicial do Bandicut

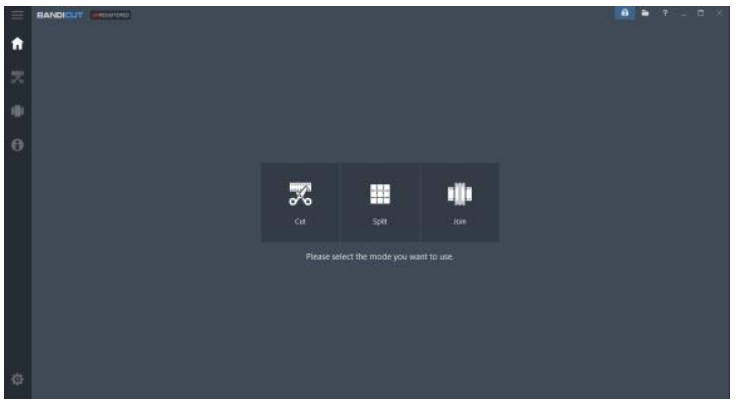

Fonte: BANDICUT Video Cutter (2018).

Como resultado do processo de seleção e edição de cenas, obtivemos arquivos de vídeo totalizando 10 minutos e 31 segundos de vídeo, retirados do filme Magnólia, e 12 minutos e 35 segundos de vídeo, do filme Bicho de Sete Cabeças. Contatamos, a seguir, a empresa selecionada para realização do processamento digital e reconhecimento e quantificação de expressões faciais, a Affectiva ${ }^{3}$. A empresa disponibiliza dois tipos de serviço: o licenciamento do software, que passa a ser de livre utilização pelo cliente que o adquire, ou o envio de arquivos de vídeo com subsequente retorno de dados coletados. Dado o 
elevado custo do licenciamento, optamos pela segunda opção. A empresa, após explicitação do propósito acadêmico de utilização do software, cedeu seus serviços gratuitamente.

Os dados retornados pela Affectiva tomam a forma de métricas em arquivos de extensão .json e .csv. Os arquivos correspondem a matrizes que identificam landmarks (pontos específicos dos rostos identificados: boca, nariz, olhos etc.) e os relacionam às emoções identificáveis: Anger (Raiva), Contempt (Desprezo), Disgust (Nojo), Fear (Medo), Joy (Alegria), Sadness (Tristeza) e Surprise (Surpresa). A empresa disponibiliza ainda uma ferramenta visual para observação dos dados coletados (Figura 3).

Figura 3 - Ferramenta visual da Affectiva: trecho do filme Magnólia (1999)

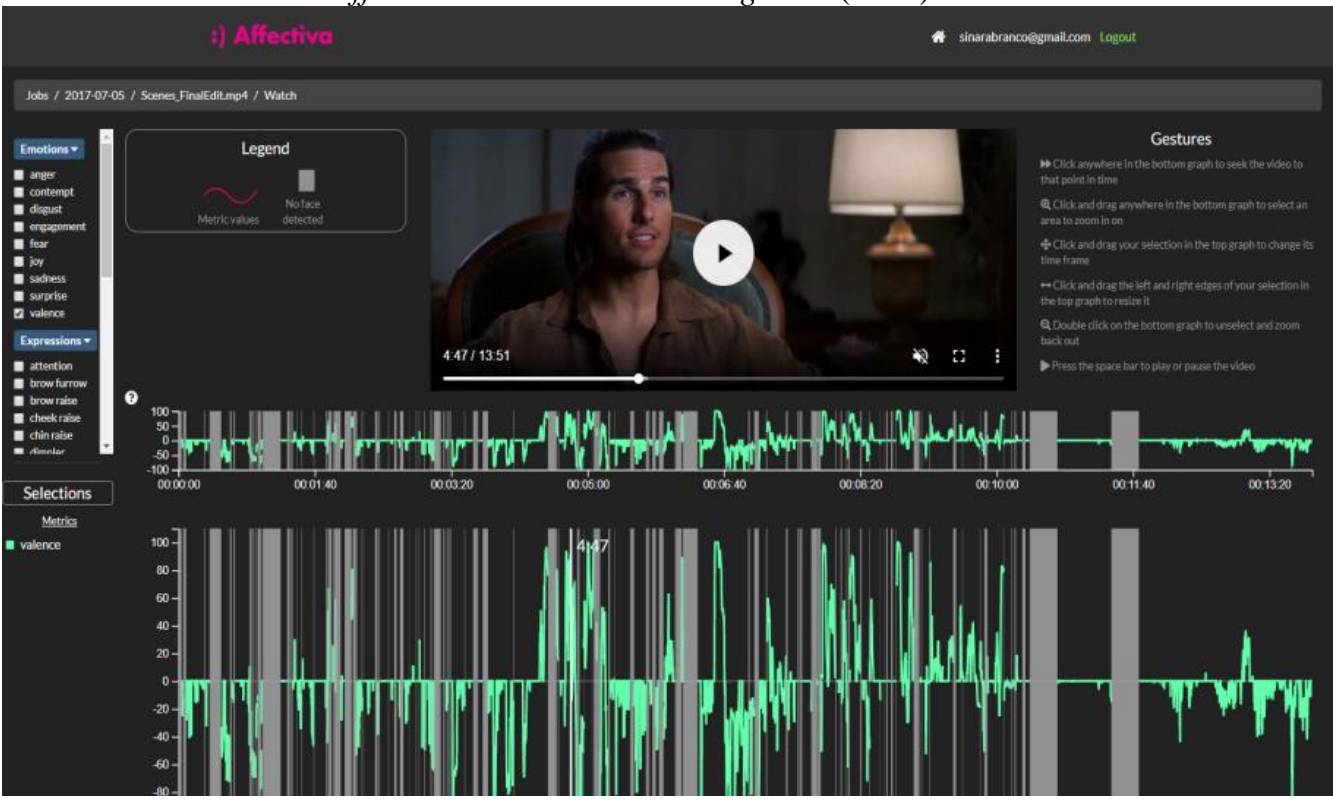

Fonte: Magnólia (1999); AFFECTIVA Emotion as a Service (2018).

Para a análise tradutória da legenda, foi construído um corpus textual paralelo contendo transcrições dos diálogos presentes nas cenas selecionadas de um lado e suas respectivas legendas de outro. Para Magnólia, foram utilizadas as legendas oficiais do DVD. Quanto ao Bicho de Sete Cabeças, devido à indisponibilidade de legendas no DVD, optamos pela utilização de legendas criadas por fãs e disponíveis on-line, no domínio opensubtitles. org $^{4}$. A análise das cenas se deu através da triangulação dos dados obtidos: da quantificação de expressões faciais resultante do processamento digital de imagens; da análise comparativa de legenda e diálogo-fonte; e de considerações a respeito das narrativas fílmicas de ambas as obras.

Para aprofundamento da análise, foi utilizado o software EMOVIE (Figura 4), desenvolvido em parceria com Projeto PIBITI - Ciclo 2017-2018, financiado pelo CNPq, 
intitulado Desenvolvimento de software para análise de expressões faciais e emocionais humanas a partir da tradução intersemiótica e processamento digital de imagens ${ }^{5}$. $\mathrm{O}$ software permite a visualização ainda mais detalhada dos dados obtidos pela Affectiva, possibilitando ao pesquisador acesso a características não disponíveis inicialmente, como visualização dos landmarks (pontos de reconhecimento facial), reconhecimento e listagem de picos de ativação emocional e cálculo de médias emocionais ao longo de trechos especificados pelo usuário.

Após a análise das cenas selecionadas inicialmente, uma segunda seleção de cenas foi realizada. Seguiram-se os mesmos procedimentos, resultando, dessa vez, em 10 minutos e 47 segundos de cenas retiradas do filme Magnólia e 6 minutos e 4 segundos retirados de Bicho de Sete Cabeças, subsequentemente analisados de maneira análoga à descrita anteriormente.

Figura 4 - Tela de utilização do EMOVIE: trecho do filme Magnólia (1999)

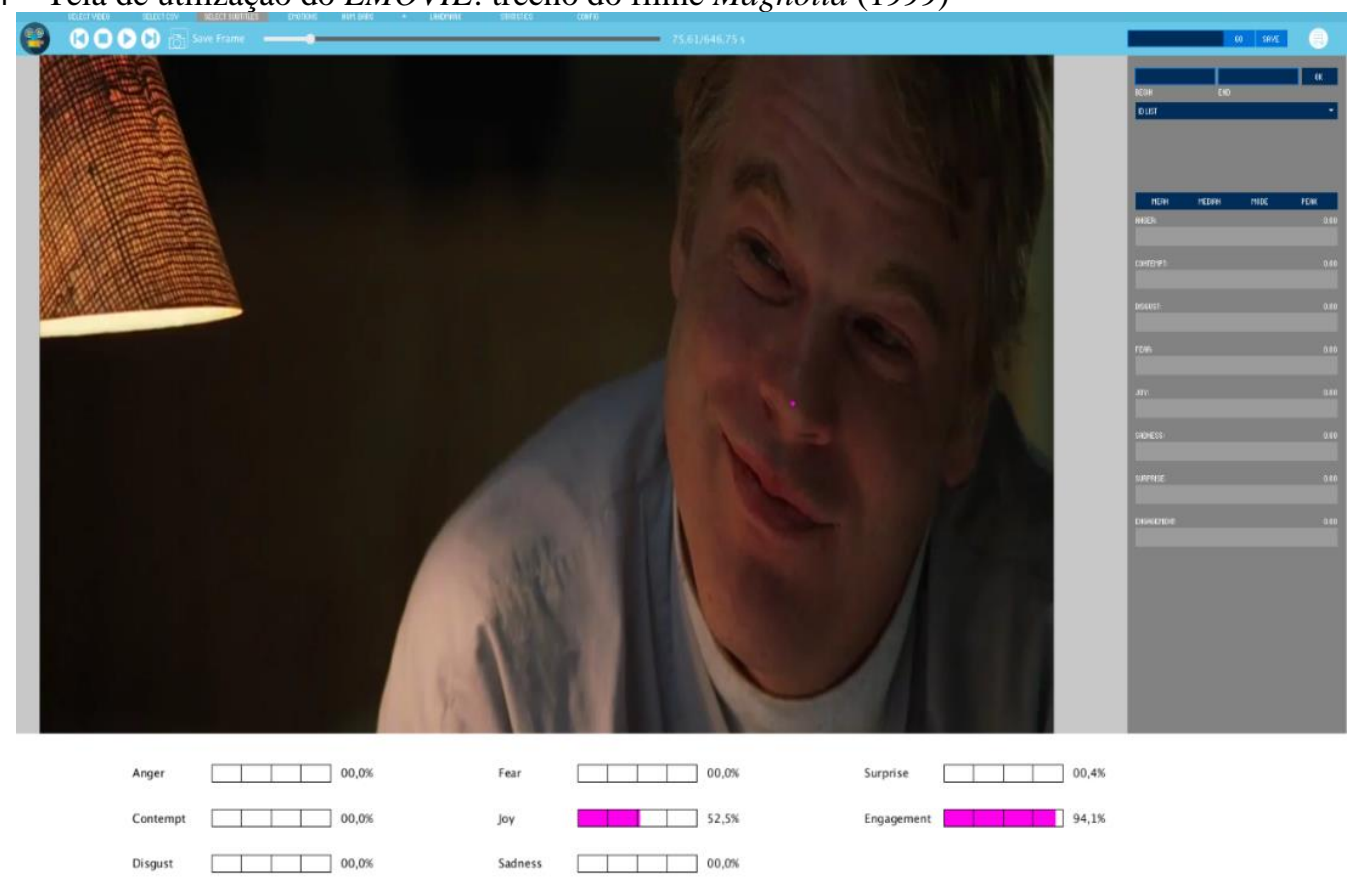

Fonte: Magnólia (1999).

\section{Análise e Discussões}

Um total de quatorze cenas foram analisadas - oito pertencentes ao filme Magnólia e seis ao Bicho de Sete Cabeças. Apresentamos a seguir a análise de três dessas cenas, selecionadas por melhor ilustrarem o processo de análise e os resultados obtidos. Para as análises das cenas aqui presentes, são inicialmente feitas descrições a respeito de suas composições cinematográficas e relevância narrativa, às quais se somam observações e 
considerações acerca do conteúdo verbal e suas respectivas legendas. Por fím, são considerados os dados obtidos através do processamento digital de imagens à luz da narrativa fílmica e das legendas, apresentados sob a forma de picos e médias emocionais apontados nos trechos selecionados.

A utilização dos dados de tal forma é justificada pela natureza das expressões faciais, identificadas como mudanças temporárias e rápidas na configuração muscular da face (EKMAN; FRIESEN, 2003), necessitando de observação de seus picos. As médias, por sua vez, permitem distinguir que emoções se fazem presentes de maneira mais constante ao longo da cena, bem como eliminar possíveis picos gerados por erros de leitura do software. Considerando-se dificuldades percebidas durante o processo de análise, foram desconsiderados trechos de reconhecimento facial intermitentes ou cuja duração total é inferior a um segundo. Tal decisão justifica-se através da observação dos landmarks apontados pelo software EMOVIE em tais momentos, que se encontram incorretamente posicionados sobre as faces dos atores ou mesmo sobre objetos presentes em cena. A eliminação de tais trechos faz-se necessária para que se descartem falsas leituras por parte do

210 software. Nesse sentido, foram desconsideradas também as emoções cujas métricas em cada cena falharam em atingir picos superiores a $1 \%$ de ativação, enquadradas, nesta análise, como margem de erro de leitura.

\subsection{Magnólia - Jim Kurring e Marcie}

Situada no início do filme, trata-se da cena que introduz Jim Kurring, um dos personagens centrais da obra, que transita por diferentes arcos narrativos. É também a única cena em que Marcie aparece, delimitando seu pertencimento à trama, centrada em Jim e no assassinato que investiga. Construída majoritariamente em campo-contracampo Over The Shoulder (enquadramentos sucessivos que alternam entre as personagens, vistas uma sobre os ombros da outra) e contando também com closes dos rostos dos atores, a cena coloca a subjetividade das personagens em foco (GAUDREAULT; JOST, 2009), enfatizando a relação dialógica de oposição estabelecida entre ambas. Ao longo da cena, há a seguinte troca entre Jim e Marcie, representada pela Figura 5 e Quadro 1. 
Figura 5 - Diálogo entre Jim e Marcie, do filme Magnólia (1999)

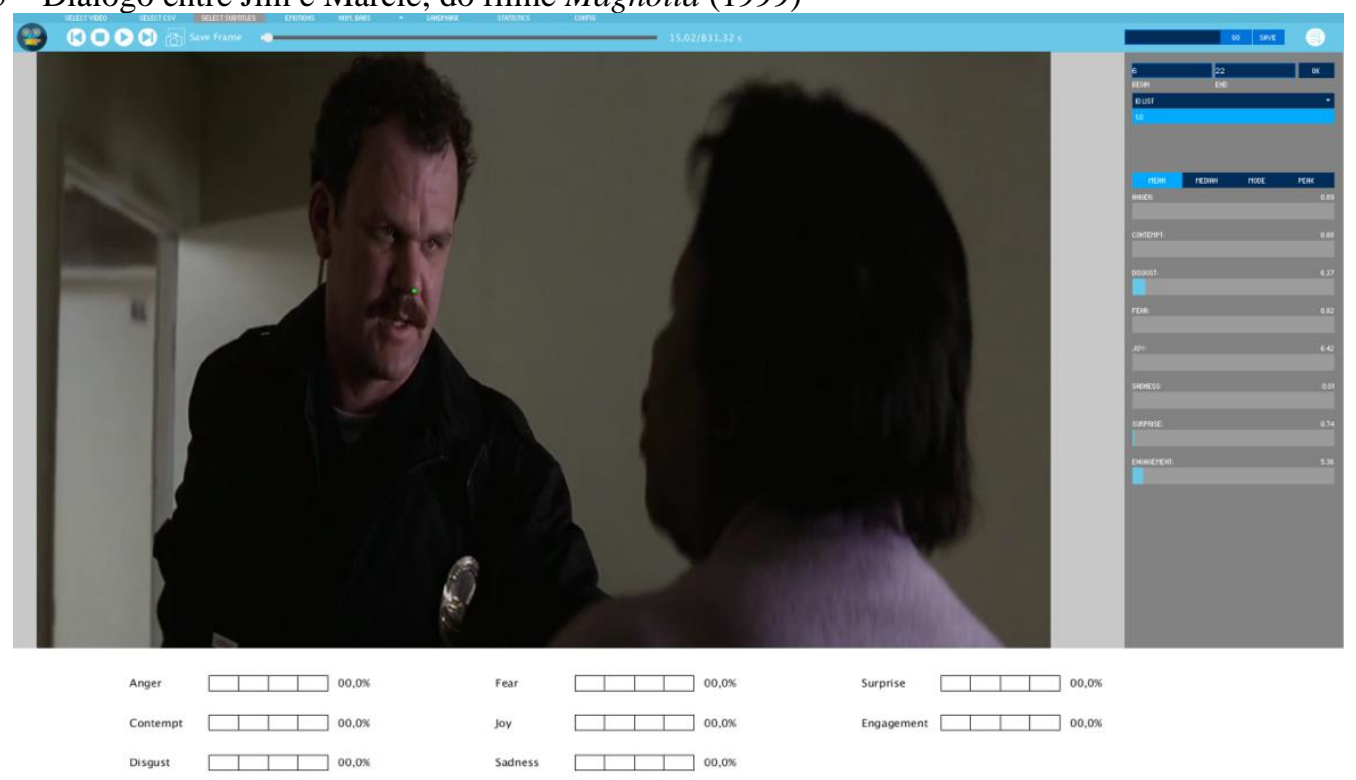

Fonte: Magnólia (1999).

\begin{tabular}{|c|c|c|}
\hline Tempo & Diálogo & Legenda \\
\hline $14: 35$ & M: There's no disturbance. & Não há tumulto algum. \\
\hline $14: 36$ & $\begin{array}{l}\text { J: OK. I got a call of a disturbance. Your } \\
\text { door was open, and I just want to see } \\
\text { what's going on. }\end{array}$ & $\begin{array}{l}\text { Ligaram falando de um tumulto. } \\
\text { Quero ver o que está acontecendo. }\end{array}$ \\
\hline $14: 40$ & M: Yeah, but there's no disturbance. & -Não há tumulto! \\
\hline $14: 42$ & $\begin{array}{l}\text { J: OK, then you got nothing to worry } \\
\text { about. }\end{array}$ & -Então, não precisa se preocupar. \\
\hline $14: 43$ & $\begin{array}{l}\text { M: You don't tell me! I know my rights! } \\
\text { Just come right in, you can't just nuh-uh! }\end{array}$ & $\begin{array}{l}\text { Não precisa me dizer! } \\
\text { Sei dos meus direitos! }\end{array}$ \\
\hline
\end{tabular}

Fonte: Magnólia (1999).

Percebemos na fala de Jim, aos 14min36s, uma série de reformulações na composição da legenda. A omissão da partícula “ $O K$ ” é a primeira delas. O legendador optou por omiti-la possivelmente devido ao fato de se tratar de uma expressão de uso corriqueiro no Brasil. A pronúncia brasileira aproxima-se da americana, e a partícula é audível em meio ao diálogo, de forma que os espectadores são capazes de compreendê-la. Além disso, a partícula possui pouca relevância, por demonstrar a intenção de Jim de acalmar Marcie, não alterando o teor do diálogo. Dessa forma, itens de baixa relevância podem ser obliterados sem que haja perda semântica (DÍAZ CINTAS; REMAEL, 2014).

A segunda reformulação diz respeito à tradução de "I got a call of a disturbance" como "ligaram falando de um tumulto". Há a passagem da voz ativa para a voz passiva e a 
consequente omissão do pronome pessoal "I", sujeito no texto-fonte, devido à transformação da emissão em frase com sujeito indeterminado. De fato, a mudança de voz em ambas as direções é prevista como uma das possíveis técnicas a serem adotadas visando a uma redução de fala nas legendas (DÍAZ CINTAS; REMAEL, 2014). Optando por utilizar tais técnicas, o legendador evita uma tradução mais literal do tipo "Eu recebi uma ligação" em prol de uma construção mais direta e curta: "Ligaram".

Ainda nesse trecho, percebemos uma última mudança efetuada durante o processo de legendagem: a omissão da sentença “your door was open”. À primeira vista, parece haver perda semântica, devido ao desaparecimento dessa informação na legenda. Isso não ocorre graças ao conceito de coesão intersemiótica, que Díaz Cintas e Remael (2014, p. 171, tradução nossa) definem como: “coesão Intersemiótica na legendagem refere-se ao modo como esta conecta diretamente a linguagem verbal à trilha sonora e às imagens na tela, utilizando as informações por elas fornecidas para criar um todo linguístico-visual coerente" ${ }^{\text {. }}$ Assim, o legendador apoia-se na redundância oferecida pelos diferentes canais comunicativos da narrativa fílmica de forma a preservar a coesão semiótica mesmo com a omissão de uma 212 sentença. Sabemos que Jim entrou pela porta aberta não apenas porque o diz. Segundos antes, podemos vê-lo fazer exatamente isso. A porta continua visível e aberta à esquerda do policial durante sua fala, como visto na Figura 5.

Tais reduções são necessárias, pois, para que as legendas funcionem de maneira satisfatória e insiram-se na obra fílmica de modo a favorecer a coesão semiótica, devem apresentar-se sincronicamente à imagem e ao som. Essa restrição temporal, associada à restrição espacial, derivada da presença física da tela no meio audiovisual, tornam a redução do número de caracteres e a simplificação de enunciados não apenas desejáveis como essenciais à prática da legendagem (DÍAZ CINTAS; REMAEL, 2014). De tal modo, tais técnicas redutoras são recorrentes e observáveis ao longo do filme. Ainda durante essa cena, uma das falas de Marcie é traduzida como mostrado na Figura 6 e no Quadro 2. 
Figura 6 - Identificação facial de Marcie, do filme Magnólia (1999)

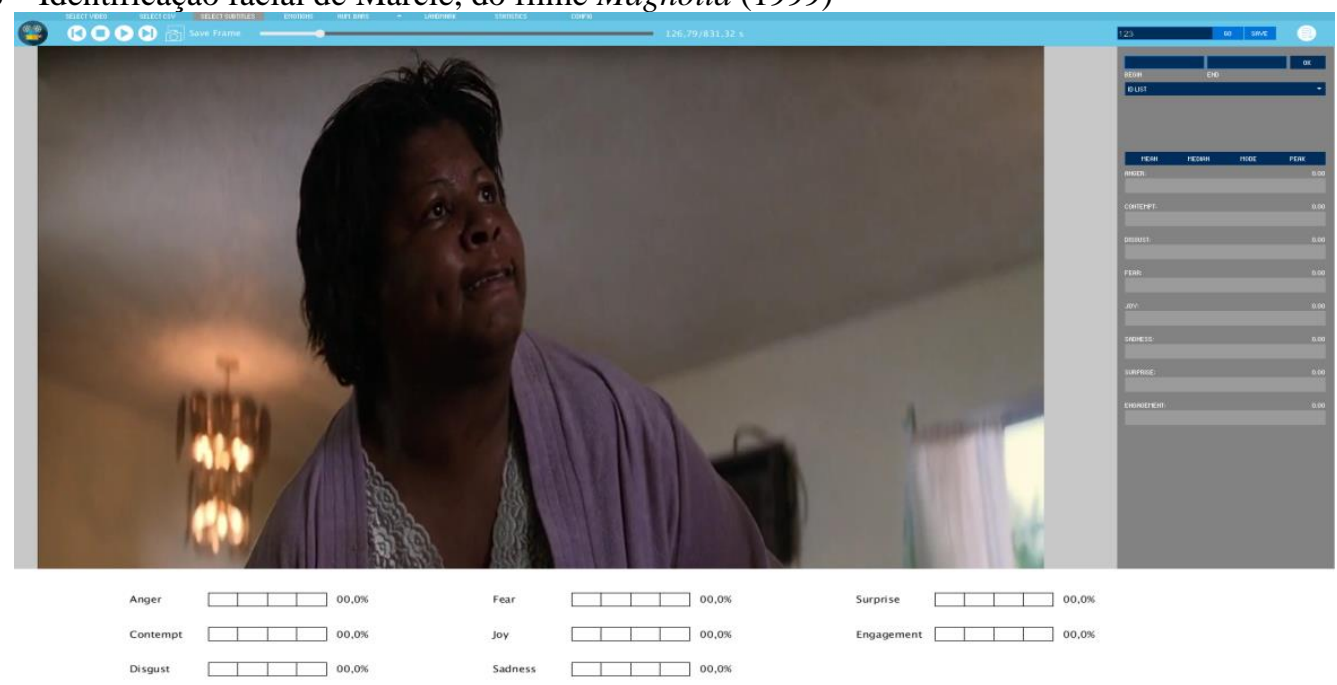

Fonte: Magnólia (1999).

Quadro 2 - Corpus Paralelo: Fala de Marcie (M), do filme Magnólia (1999)

\begin{tabular}{|c|l|l|}
\hline Tempo & Diálogo & Legenda \\
\hline $17: 18$ & $\begin{array}{l}\text { M: There's nobody in my motherfucking } \\
\text { closet! }\end{array}$ & - Não tem ninguém no armário! \\
\hline
\end{tabular}

Fonte: Magnólia (1999).

Díaz Cintas e Remael (2014) identificam a linguagem emocionalmente carregada (como palavras tabus, palavrões ou interjeições) como possíveis itens a serem reduzidos ou omitidos. Os autores enfatizam, entretanto, que em alguns casos tal linguagem pode desempenhar um papel vital na obra da qual fazem parte, ficando a critério do legendador reconhecer em que momento tal omissão é apropriada.

No trecho acima, o legendador opta, nesse momento, por apagar a linguagem emocionalmente carregada. Tal característica tradutória se faz presente não somente nessa cena, mas é perceptível ao longo do filme. Nesse caso especificamente, não há perdas para o espectador, capaz de identificar a raiva e o medo de Marcie através de sua linguagem corporal agressiva e de suas expressões faciais.

O software de processamento digital apresenta certos problemas ao longo da cena. Em primeiro lugar, apesar da boa iluminação e do enquadramento favorável para o olho humano, a captura das expressões faciais de Marcie pelo software é intermitente e insatisfatória, contando com longos períodos de não identificação (como nas Figuras 6 e 7). Nos momentos em que há o reconhecimento de seus landmarks, as leituras são tímidas e inexpressivas, com médias e picos baixos, de modo a serem desconsiderados. 
Figura 7 - Captura falha do rosto de Marcie, Magnólia (1999)

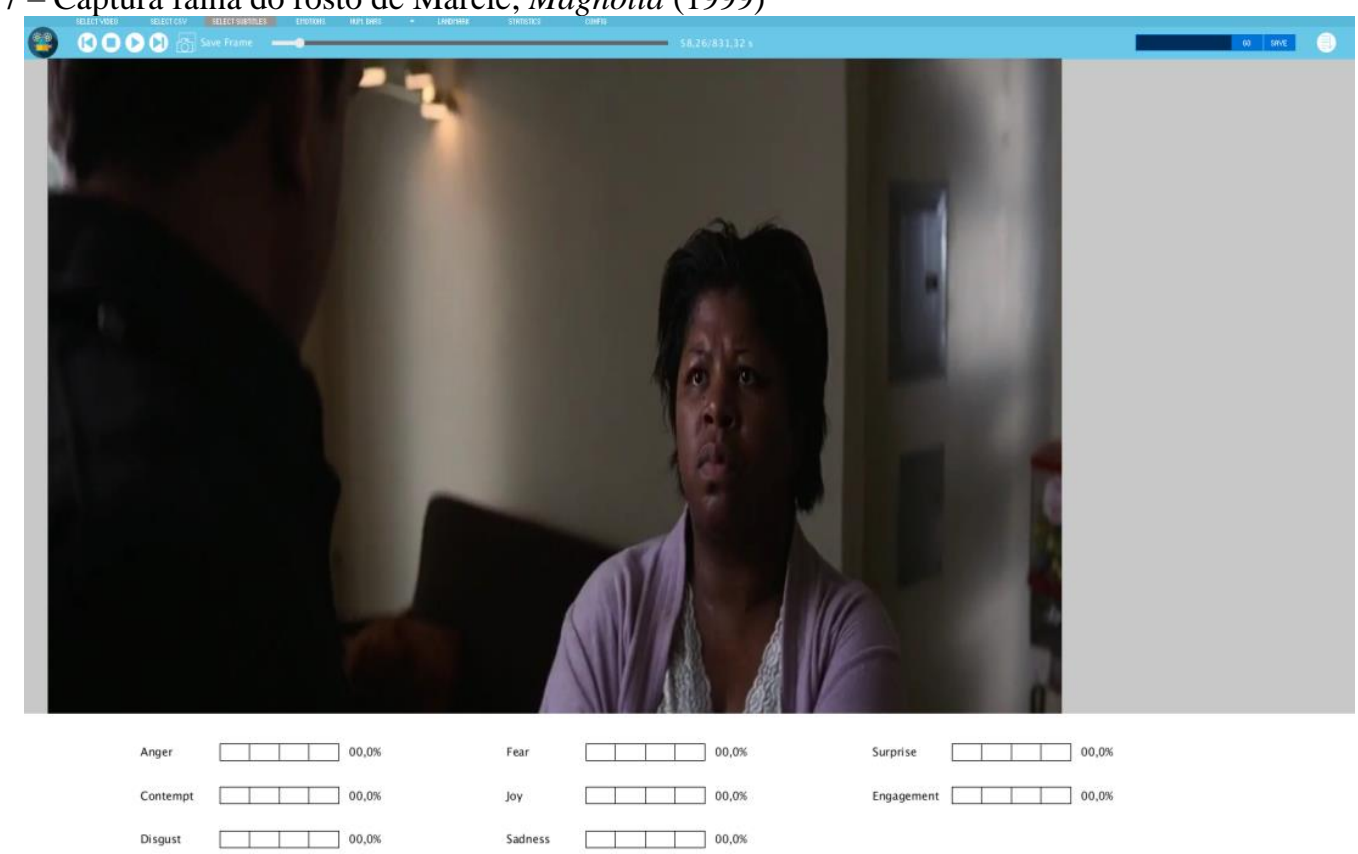

Fonte: Magnólia (1999).

Quanto a Jim, o software realiza a captura de sua face durante intervalos mais longos, mas ainda de forma insatisfatória. Durante um desses intervalos, de duração de 16 segundos, o software oferece a leitura disponível na Tabela 1, ilustrada pela Figura 8.

Figura 8 - Captura das expressões de Jim, Magnólia (1999)

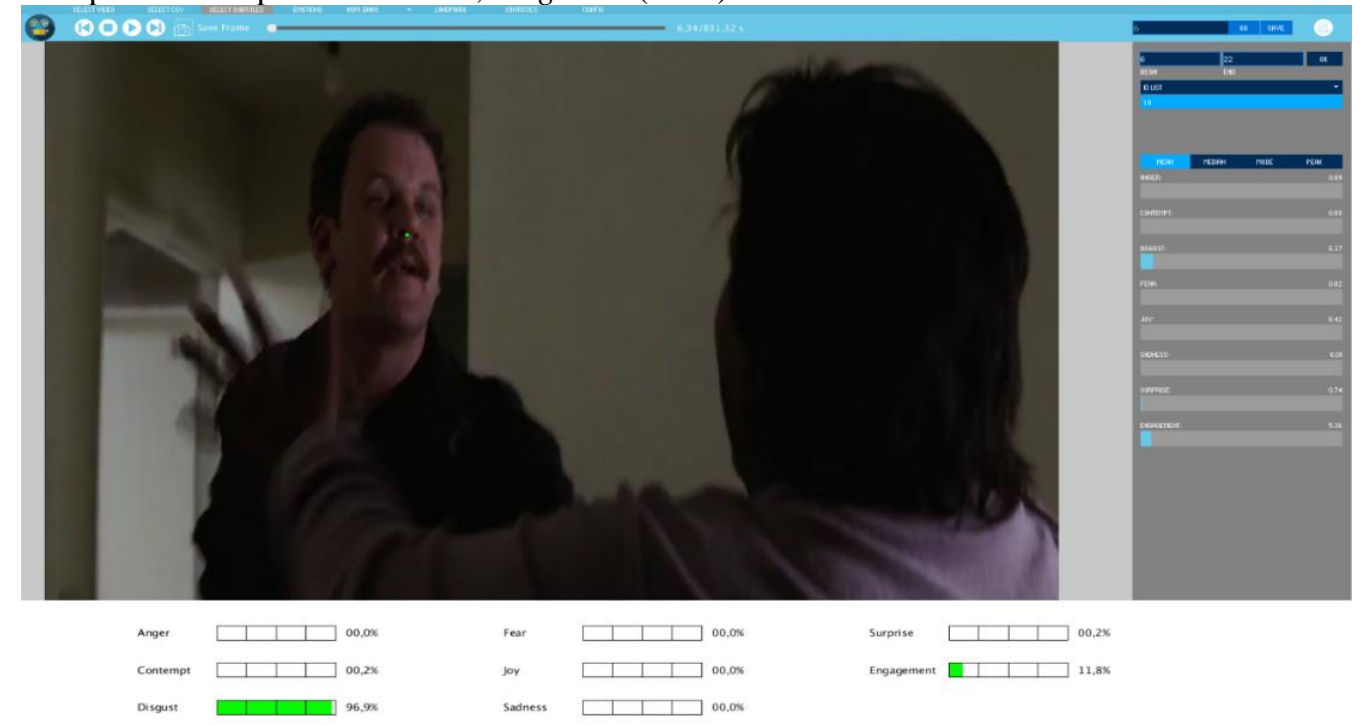

Fonte: Magnólia (1999). 
Tabela 1 - Dados emocionais das expressões de Jim

\begin{tabular}{|l|l|l|}
\multicolumn{1}{c}{ Emoção } & \multicolumn{1}{c|}{ Pico } & \multicolumn{2}{c}{ Média } \\
\hline Anger (Raiva) & 6.99 & 0.09 \\
\hline Contempt (Desprezo) & 2.45 & 0.08 \\
\hline Disgust (Nojo) & 99.88 & 6.37 \\
\hline Surprise (Surpresa) & 24.51 & 0.74 \\
\hline
\end{tabular}

Fonte: elaboração própria.

Observando as médias e picos, a única emoção apontada com certa constância e relevância é Disgust (Nojo). Entretanto, esse apontamento não condiz com a leitura realizada pelos pesquisadores, destoando do propósito narrativo da cena. Desse modo, a utilização do software de processamento digital revela-se insatisfatória durante essa cena.

\subsection{Magnólia - Linda e Dr. Lanyon}

Linda é uma das personagens principais do filme. Representada de maneira errática e depressiva, a construção da personagem centra-se em seu relacionamento com Earl Partridge (Jason Robards), um velho magnata televisivo. Ao longo do filme, Linda revela ter se casado com Earl buscando aproveitar-se de seu dinheiro e de sua idade já avançada para enriquecer através de uma herança. Com Earl acometido de câncer pulmonar em estágio avançado e em seu leito de morte, Linda sofre com a culpa do relacionamento que construiu baseado em mentiras e traições. Dizendo-se perdidamente apaixonada por seu marido moribundo e devastada pela culpa, Linda tenta, durante os momentos finais do filme, suicidar-se.

O relacionamento entre Linda e Earl, entretanto, não é claro desde o início. Linda nos é apresentada durante a sequência introdutória do filme, que passeia em pequenas tomadas pelos principais personagens da trama. Nesse momento, Linda é vista em sua casa, ao telefone, bastante irritada e gritando que ele (Earl) precisa de mais comprimidos. Após beijar a testa de seu marido, dizendo que o ama, Linda sai tempestuosamente de casa.

$\mathrm{Na}$ próxima cena em que vemos a personagem, tendo mais informações sobre ela, Linda encontra-se no escritório de Dr. Lanyon, o médico de seu marido. Parecendo emocionalmente abalada, Linda mantém-se inquieta, andando pelo escritório, gesticulando e gaguejando, exigindo que o médico lhe diga o que fazer e reclama que os analgésicos que Earl toma não estão mais funcionando. Dr. Lanyon pede que Linda se acalme, explicando a possibilidade de utilização de morfina líquida. $\mathrm{O}$ uso desse medicamento certamente aliviaria a dor de Earl, mas acabaria por apagar os últimos traços reconhecíveis de sua personalidade. Nos momentos finais da cena, temos o diálogo exibido no Quadro 3. 
Figura 9 - Linda conversa com Dr. Lanyon e sorri, Magnólia (1999)

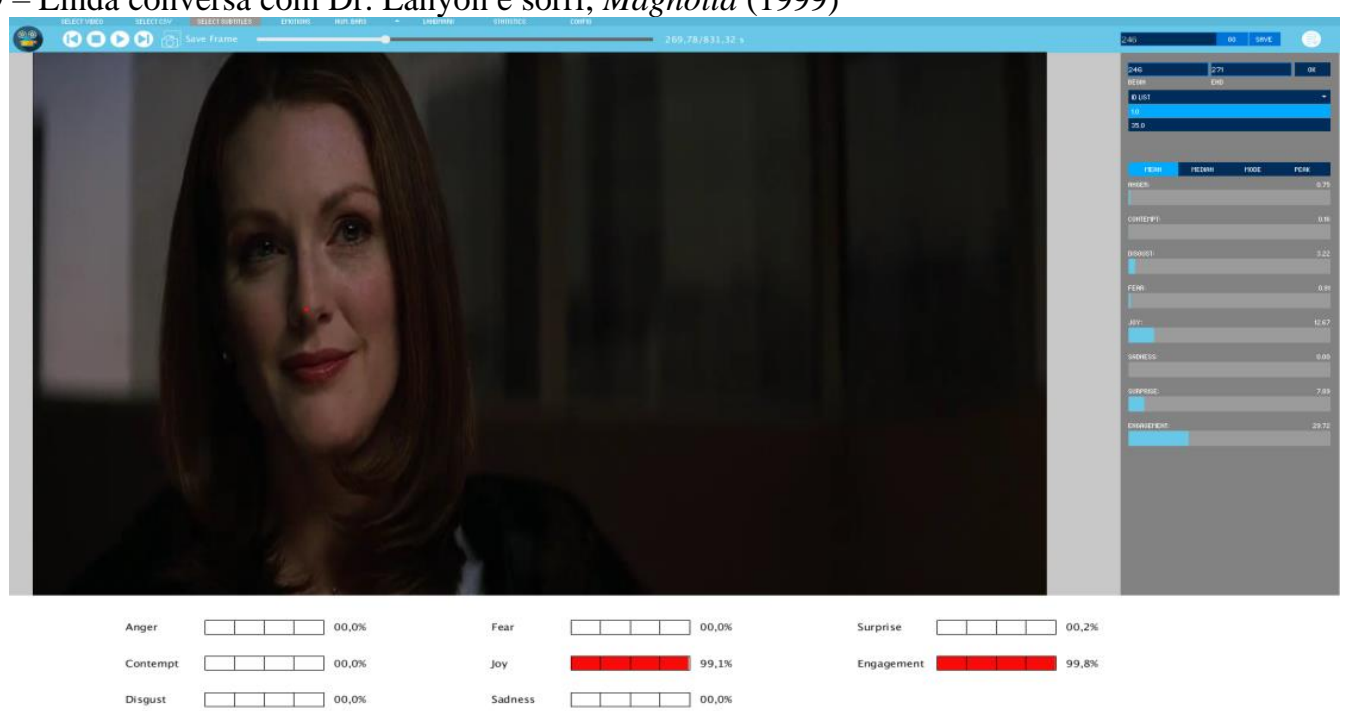

Fonte: Magnólia (1999).

Quadro 3 - Corpus Paralelo: Diálogo entre Linda (L) e Dr. Lanyon (DL), Magnólia (1999)

\begin{tabular}{|c|c|c|}
\hline Tempo & Diálogo & Legenda \\
\hline $19: 49$ & $\begin{array}{l}\text { DL: But you need to realize that, um... } \\
\text { Once you give it to him }\end{array}$ & $\begin{array}{l}\text { Mas você tem que entender que... } \\
\text { uma vez que der para ele, }\end{array}$ \\
\hline $19: 53$ & DL: there's no going back. & não ficará mais lúcido. \\
\hline $19: 55$ & DL: It will certainly cure his pain... & $\begin{array}{l}\text { Ele não } \\
\text { sentirá mais dor, mas... }\end{array}$ \\
\hline $19: 57$ & $\begin{array}{l}\text { DL: But he will drift in and out of } \\
\text { consciousness }\end{array}$ & $\begin{array}{l}\text { oscilará entre a consciência } \\
\text { e a inconsciência }\end{array}$ \\
\hline $19: 59$ & $\begin{array}{l}\text { DL: even worse than he is now. And I } \\
\text { mean... }\end{array}$ & de modo ainda pior. \\
\hline 20:02 & $\begin{array}{l}\text { DL: All sign of the recognizable Earl will } \\
\text { pretty much go away. }\end{array}$ & $\begin{array}{l}\text { As características pessoais de } \\
\text { Earl praticamente desaparecerão. }\end{array}$ \\
\hline 20:09 & L: I- Wh- What the fuck can I say to th- & Que posso dizer diante disso? \\
\hline 20:11 & L: I don't know what to say to that. & $\begin{array}{l}\text { Não sei } \\
\text { o que dizer! }\end{array}$ \\
\hline
\end{tabular}

Fonte: Magnólia (1999).

Diante dessas informações, Linda hesita, gagueja, inicia uma fala emocionalmente carregada e para, corrigindo-a para uma expressão mais polida. Construída, sobretudo, em closes faciais, a cena culmina com um destaque ainda maior para a expressão facial da personagem, quando a câmera permanece estática em seu rosto e Linda, diante da informação de que seu marido em breve deixará de existir, sorri (Figura 9).

Seu sorriso ao final da cena vai de encontro ao seu comportamento durante os minutos prévios, quando parecia inquieta, incontida e irritada. Nesse sentido, seu sorriso aparenta ser falso ou ambíguo. Não é possível identificar o que Linda sente com a proximidade da morte 
de seu marido. Sua irritação poderia ser justificada tanto pelo desespero de perder o homem que realmente ama quanto pela irritação de ter que lidar com a doença do seu marido enquanto apenas deseja sua herança. Não há clareza sobre o que motiva sua expressão: a ocultação de uma dor genuína ou a formalidade diante de uma notícia que a agrada.

Seja qual for a interpretação dada à cena pelo espectador, a carga emocional da personagem e sua ambiguidade permanecem centrais à sua construção e são exacerbadas ao longo dessa cena. A legendagem, entretanto, opta pela redução através da normalização das emissões verbais da personagem. Os gaguejos não podem ser descritos e reformulações de sua fala são obliterados, bem como os palavrões por ela utilizados. Díaz Cintas e Remael (2014, p. 165) preveem a redução de repetições e expletivos como uma possibilidade tradutória, mas atentam para a importância do contexto fílmico ao optar por tais reduções.

A tradução para a enunciação "I- Wh- What the fuck can I say to th-" ("Que posso dizer diante disso?”), por exemplo, não apenas apaga as hesitações e a repetição iniciais, como também ignora a interrupção abrupta da frase e o palavrão utilizados por Linda, reduzindo o conteúdo emocional da frase. A tradução presente na legenda é, ainda, demasiadamente formal e bem construída para uma fala dita momentos após o recebimento de uma notícia chocante a respeito de um cônjuge.

Desse modo, o legendador distancia-se do conteúdo emocional da cena, podendo diminuir, sob o ponto de vista do espectador não falante de inglês, a inquietação de Linda e sua ambiguidade, tão importantes para a sua construção. Uma tradução que acenasse de maneira mais significativa para a subjetividade da personagem, mantendo parte de suas hesitações, talvez fosse preferível. Felizmente, tal perda é diminuída (ou talvez até mesmo negada) pela atuação de Julianne Moore, que transmite a irritabilidade e o desespero da personagem através de sua linguagem corporal e expressões faciais.

O software de reconhecimento facial capta a face da personagem de maneira satisfatória durante os 25 segundos totais de close em seu rosto, oferecendo os dados apresentados abaixo (Figura 10, Tabela 2). Percebe-se, pela análise de picos e médias, como as emoções Alegria, Surpresa e Nojo são as principais apontadas. 
Figura 10 - Captura das expressões faciais de Linda, Magnólia (1999)

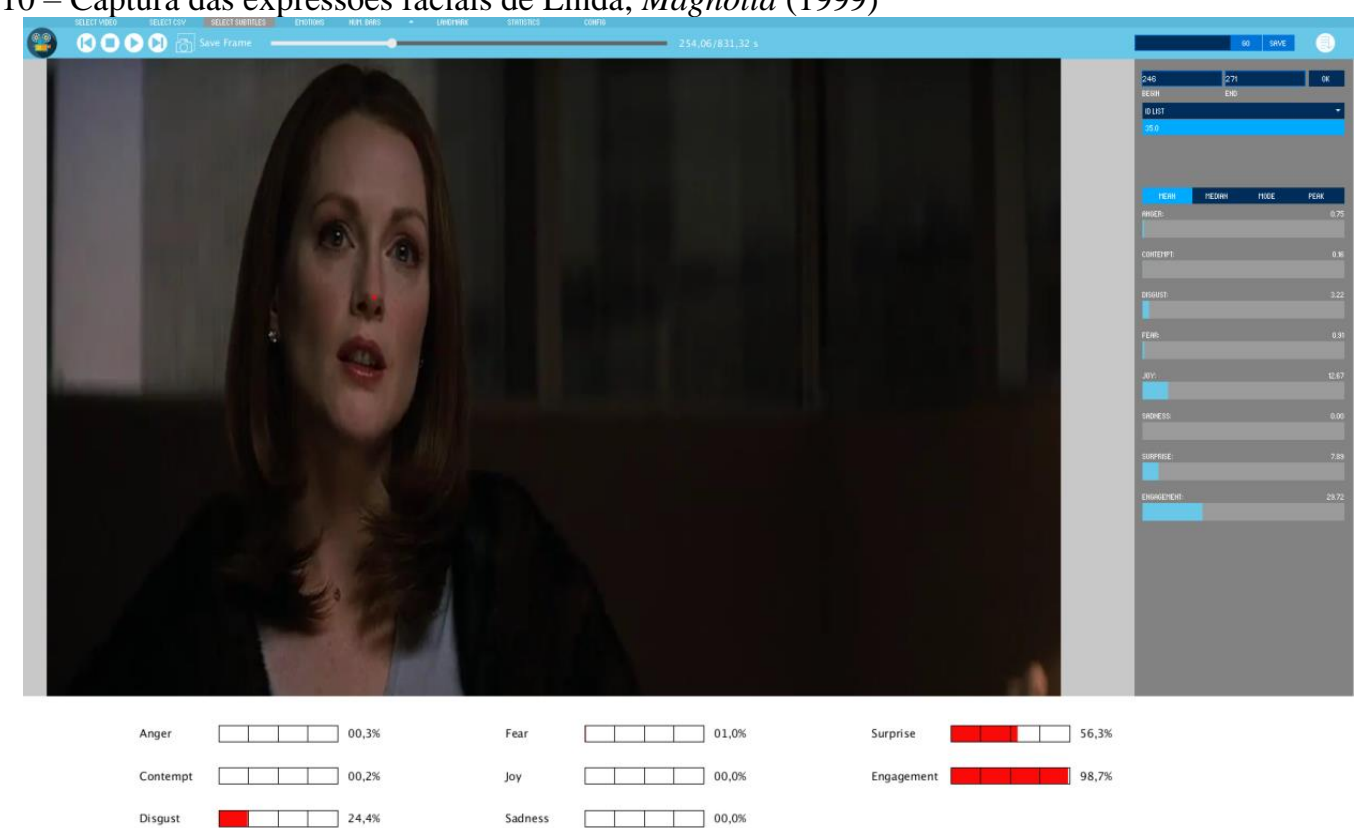

Fonte: Magnólia (1999).

Tabela 2 - Dados emocionais das expressões de Linda

\begin{tabular}{|l|c|c|}
\hline \multicolumn{1}{|c|}{ Emoção } & Pico & Média \\
\hline Anger (Raiva) & 8.63 & 0.75 \\
\hline Disgust (Nojo) & 50.43 & 3.22 \\
\hline Fear (Medo) & 10.91 & 0.91 \\
\hline Joy (Alegria) & 99.33 & 12.67 \\
\hline Surprise (Surpresa) & 60.04 & 7.89 \\
\hline
\end{tabular}

Fonte: elaboração própria.

A predominância da Alegria como emoção identificada é explicável pela presença do sorriso da personagem durante os segundos finais da cena, que se constitui como o denominador mais reconhecível de tal emoção (EKMAN; FRIESEN, 2003). Um espectador humano, entretanto, ao observar tal expressão situada no contexto da narrativa fílmica, dificilmente apontaria, em seu sorriso, a presença de uma alegria espontânea e genuína. Demarca-se, desse modo, um dos pontos de dificuldade na utilização do software: sua incapacidade de lidar com o contexto, por realizar suas leituras na imediatez da imagem isolada, quadro a quadro.

Quanto às demais emoções apontadas, as leituras oferecidas para Raiva e Medo são bastante tímidas. Ainda assim, seu aparecimento não gera estranheza, dada a congruência com o contexto fílmico. O mesmo é verdade para a Surpresa, apontada como a segunda emoção predominante na cena. Não há, para tais emoções, grande distanciamento entre a leitura 
oferecida pelo software e possíveis interpretações espectatoriais, constituindo-se de tal modo em uma leitura satisfatória por parte do software de processamento digital.

A última emoção apontada pelo software (Nojo), contudo, distancia-se da interpretação dos pesquisadores. Não parece haver, considerando-se o contexto e o comportamento da personagem, a presença de nojo em suas falas e ações. O apontamento dessa emoção, como demonstrado anteriormente, é recorrente ao longo do filme e para diversas personagens em situações em que parece inadequado, sendo explicado pela configuração facial dos atores e atrizes capturados. Constitui-se, portanto, em outra dificuldade observada na utilização do software, revelada durante a análise.

A seguir, apresentaremos considerações sobre o filme Bico do Sete Cabeças.

\subsection{Bicho de Sete Cabeças - Chegada de Neto ao manicômio}

Os momentos iniciais do filme mostram o relacionamento difícil entre Neto (Rodrigo Santoro) e sua família, sobretudo seu pai, Wilson (Othon Bastos), que se opõe ao seu estilo de vida: suas amizades, suas roupas, seu "comportamento rebelde". O desentendimento entre pai e filho atinge o auge quando, após voltar para casa, Neto larga seu casaco na sala e seu pai encontra um cigarro de maconha escondido em um dos bolsos. A partir desse momento, Wilson assume que seu filho seja viciado e decide, sem comunicá-lo, interná-lo em um manicômio.

Na cena aqui analisada, Neto é levado à instituição manicomial onde será internado sob o pretexto de visitar um amigo de seu pai. Lá chegando, acompanhamos a cena através do ponto de vista do garoto, que observa Wilson conversar com a atendente sem de fato ouvi-la. Escutamos somente, como trilha sonora diegética, o rock agressivo que o adolescente ouve em seus fones de ouvido. A opção por apagar o diálogo e manter apenas a música diegética audível aproxima o espectador da subjetividade da personagem (GAUDREAULT; JOST, 2009), servindo também de prenúncio das agressões e abusos que o adolescente está prestes a sofrer: Neto é subitamente agarrado por dois enfermeiros que o arrastam, sob gritos de protesto e chamados pelo pai, que se retira do local, até a sala de triagem. Lá, é examinado por Marcelo (Luís Miranda), um dos enfermeiros da instituição.

O exame ao qual é submetido consiste em uma série de perguntas feitas por Marcelo, todas relacionadas ao uso de drogas. Enquanto o jovem tenta explicar-se e nega ser viciado, o que diz é ignorado ou refutado. Durante os momentos iniciais da cena, Marcelo sequer enxerga o paciente à sua frente; concentrando-se, em vez disso, em escrever em sua 
prancheta. Quando, finalmente, olha o rosto de Neto, o faz erguendo o nariz, olhando-o de cima para baixo e agressivamente perguntando: "Escuta, você fuma maconha?" (Figura 11). Ao fundo, vemos um dos enfermeiros que agarrou Neto parado em frente da porta, agindo como guarda prisional. Enquanto isso, outro enfermeiro prepara uma injeção de calmantes, aplicada forçosamente em Neto ao final da cena, sem que ele receba qualquer explicação.

O filme chega, nesse momento, ao seu principal conflito e tema central: os abusos e preconceitos sofridos por pacientes manicomiais no Brasil. A narrativa esforça-se para ilustrar tais temas através da confusão de Neto diante das agressões sofridas de maneira tão abrupta e rápida (a cena dura menos de 2 minutos), bem como por meio da relação de poder dos enfermeiros sobre Neto, pautada no preconceito desde o início.

A legendagem da cena, entretanto, trai tais características. As traduções presentes no Quadro 4 dizem respeito a trechos do diálogo da cena. De especial interesse, são as falas de Marcelo, nas quais o legendador opta pela tradução de "maconha" como "pot" e "cigarro de maconha" como "joint".

220 Figura 11 - Neto observado por Marcelo em cena de Bicho de Sete Cabeças (2001)

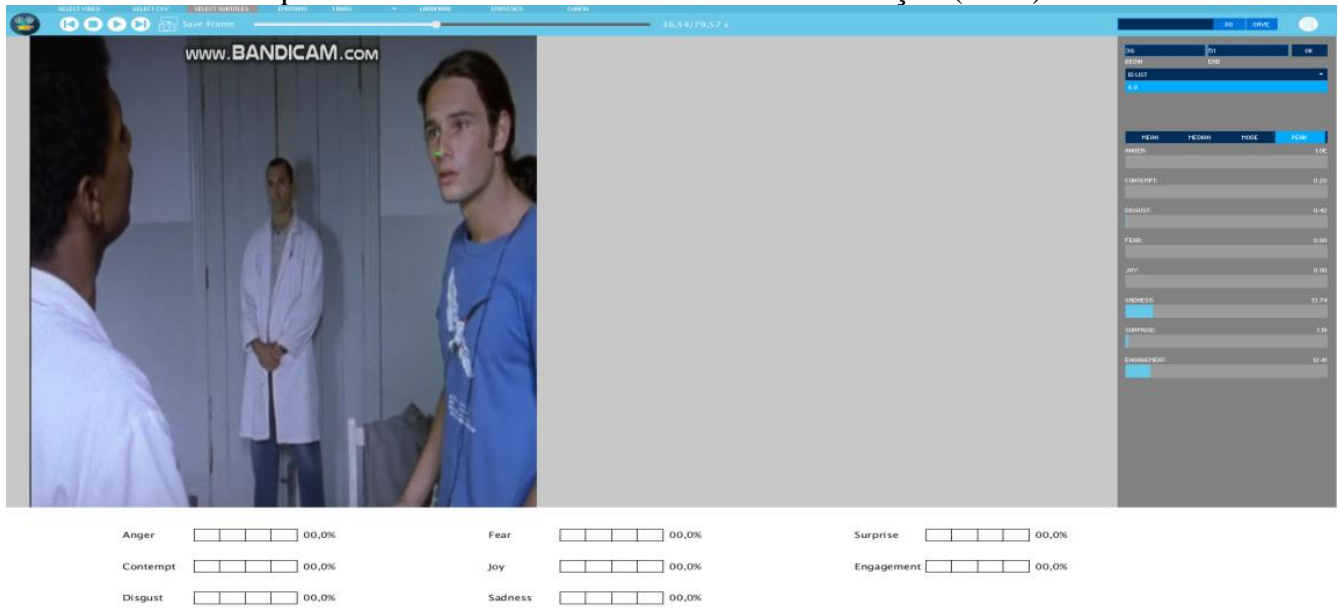

Fonte: Bicho (2001) 
Quadro 4 - Corpus Paralelo: Diálogo entre Neto (N) e Marcelo (Ma), do filme Bicho de Sete Cabeças (2001)

\begin{tabular}{|l|l|l|}
\hline $00: 22: 12$ & $\begin{array}{l}\text { N: Peraí, peraí, deixa eu tirar aqui. } \\
\text { Ma: Fica tranquilo que tá tudo bem. }\end{array}$ & $\begin{array}{l}\text {-Wait a minute. Let me get thi } \\
\text {-Relax, man. }\end{array}$ \\
\hline $00: 22: 45$ & $\begin{array}{l}\text { N: Amigo, isso é um mal-entendido, eu } \\
\text { vou chamar meu pai pra esclarecer... } \\
\text { Ma: Escuta, você fuma maconha? }\end{array}$ & $\begin{array}{l}\text {-It's a mistake, I'll call him to } \\
\text {-Listen, do you smoke dope? }\end{array}$ \\
\hline $00: 22: 53$ & $\begin{array}{l}\text { Ma: Disse que encontrou um cigarro de } \\
\text { maconha no bolso da sua blusa... }\end{array}$ & $\begin{array}{l}\text { He found a joint in } \\
\text { your sweat shirt (sic) pocket. }\end{array}$ \\
\hline $00: 23: 21$ & $\begin{array}{l}\text { Ma: Todo mundo que foi internado aqui } \\
\text { por causa de pico começou com maconha. }\end{array}$ & $\begin{array}{l}\text { Those in here for heroin } \\
\text { once began with pot. }\end{array}$ \\
\hline
\end{tabular}

Fonte: Bicho (2001).

Optar por gírias como "pot" e "joint", bem como por uma expressão informal como "Relax, man" seriam escolhas justificáveis caso pertencessem à fala de Neto, um jovem usuário inserido na cultura das drogas e, portanto, provavelmente conhecedor ou utilizador de tais gírias. Para Marcelo, entretanto, tais escolhas parecem deslocadas quanto ao contexto fílmico. O nível de informalidade e as gírias presentes na tradução não condizem com o diálogo-fonte e acabam por distanciar o espectador não falante de português do teor abusivo do relacionamento estabelecido entre as duas personagens.

Marcelo parece, a partir da legenda, comportar-se não preconceituosamente, falando a partir de sua imaginada superioridade moral, mas como um igual, alguém que parece também estar envolvido na cultura dos usuários de drogas. Trata-se de um distanciamento do sentido do texto-fonte, construído de forma a expor o que a legenda parece obscurecer: as desigualdades encontradas nas relações estabelecidas entre pacientes manicomiais e a equipe médica dessas instituições. Ainda assim, a construção fílmica da cena, pautada, sobretudo, em exacerbar a oposição das personagens a partir da trilha sonora, do enquadramento e das expressões corporais e faciais de ambas, demonstra ao espectador o desnível de poder estabelecido entre as duas personagens.

O processamento digital, por sua vez, revelou-se de certa dificuldade. Como primeiro empecilho, coloca-se uma característica recorrente na linguagem cinematográfica brasileira, bastante presente em Bicho de Sete Cabeças: o baixo uso de câmeras estáticas e a presença de poucos closes faciais. Tais fatores, associados, possivelmente, à reduzida qualidade de vídeo na produção da obra, que data do ano 2001, sem remasterização, acabam por render leituras de expressão facial menos satisfatórias do que o esperado.

Ao longo de 1 minuto e 20 segundos de cena selecionados para processamento, apenas dois trechos, de 5 e 6 segundos de captura, respectivamente, foram possíveis, o primeiro dos 
quais se encontra ilustrado pela Figura 11 e o segundo pela Figura 12. Os dados disponíveis nas Tabelas 3 e 4 dizem respeito a tais trechos.

Figura 12 - Captura das expressões faciais de Neto, Bicho de Sete Cabeças (2001)

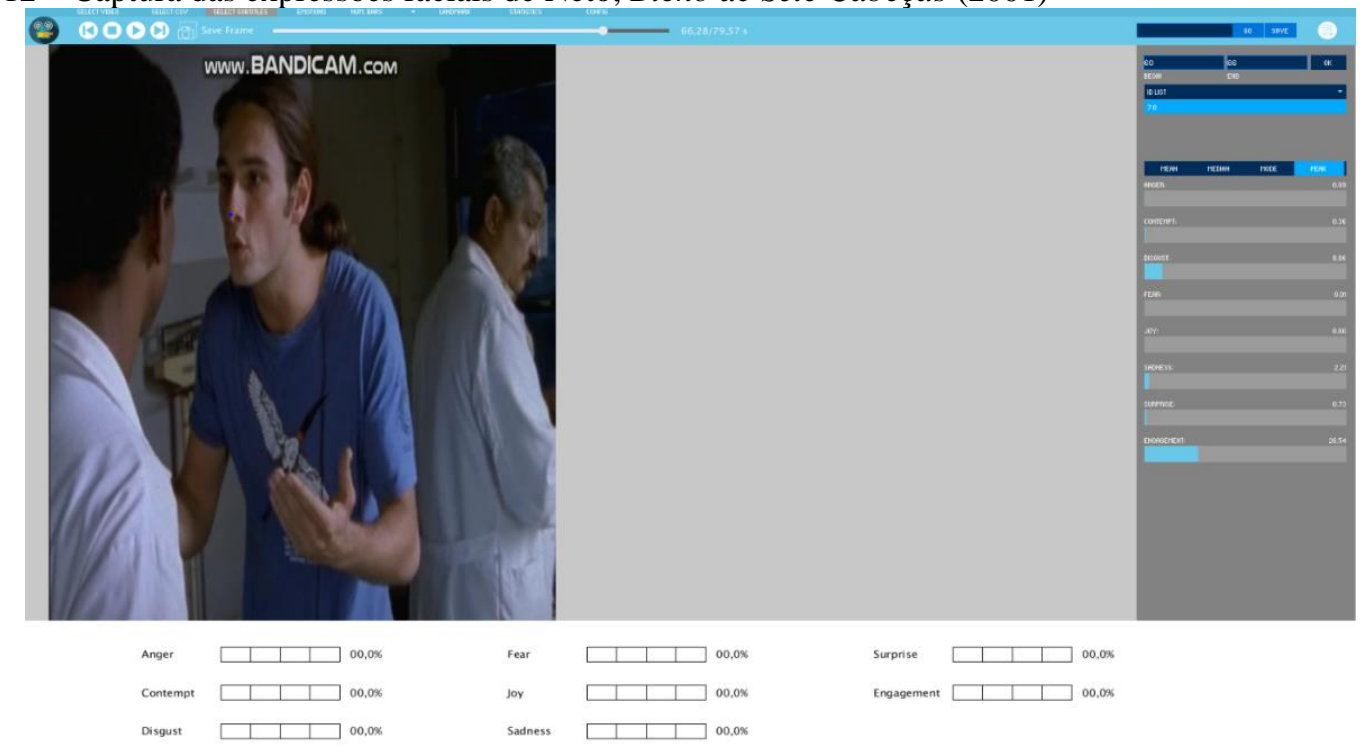

Fonte: Bicho (2001)

Tabela 3 - Dados emocionais das expressões de Neto

\begin{tabular}{|l|c|c|}
\hline \multicolumn{1}{|c|}{ Emoção } & Pico & Média \\
\hline Sadness (Tristeza) & 13.74 & 0.29 \\
\hline Surprise (Surpresa) & 1.19 & 0.02 \\
\hline
\end{tabular}

Elaboração: os autores

Tabela 4 - Dados emocionais das expressões de Neto

\begin{tabular}{|l|c|c|}
\hline \multicolumn{1}{|c|}{ Emoção } & Pico & Média \\
\hline Disgust (Nojo) & 8.86 & 0.33 \\
\hline Sadness (Tristeza) & 2.21 & 3.22 \\
\hline
\end{tabular}

Elaboração: os autores

É perceptível, apenas pela observação das médias emocionais, que os picos apontados duram frações de segundo e, dadas suas baixas ativações, não há leitura emocional relevante durante a cena. Uma das justificativas para tal fato dá-se pela tradução do choque de Neto sob a forma de neutralidade facial. Durante os breves momentos capturados, há, de fato, pouca ativação de grupos musculares em sua face. Uma inspeção mais minuciosa dos landmarks apontados pelo software durante tais trechos também revela flutuações, indicando uma possível dificuldade do software em reconhecer a face, possivelmente, devido à angulação, o 
que também explicaria a leitura insatisfatória. De todo modo, parece improvável que um observador humano, inserido como espectador na narrativa fílmica, aponte em Neto qualquer tipo de neutralidade emocional. Reforça-se, dessa forma, o ponto discutido anteriormente; a incapacidade do software em lidar com o contexto fílmico.

\section{Conclusão}

Ao concluir o estudo, reitera-se a relevância do conceito de coesão semiótica, como defendido por Díaz Cintas e Remael (2014), que enxergam a necessidade de considerar o processo de legendagem como parte constitutiva da produção de obras fílmicas, considerada a condição da legenda como canal fundamental de comunicação verbal estabelecido entre o espectador não falante da língua-fonte do texto audiovisual e a narrativa fílmica. Nesse sentido, ao serem aplicadas as diferentes e possíveis técnicas de redução e omissão textual de forma a adequar a legenda ao meio audiovisual, dotado de restrições espaciais e temporais, o emprego de tais técnicas tradutórias devem considerar o contexto da narrativa fílmica, imbricando-a em seus quatro canais: o verbal e o não verbal imagéticos e o verbal e o não verbal sonoros. Construímos os Gráficos 1 e 2 a partir de tais considerações, nos quais se organizam as quatorze cenas analisadas quanto às suas características de legendagem.

Gráficos 1 e 2 - Perdas espectatoriais considerada a legendagem

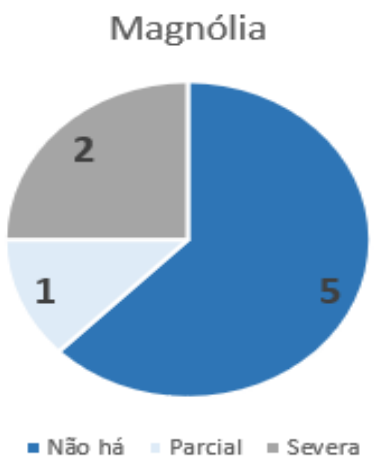
Bicho de Sete Cabeças

Elaboração: os autores

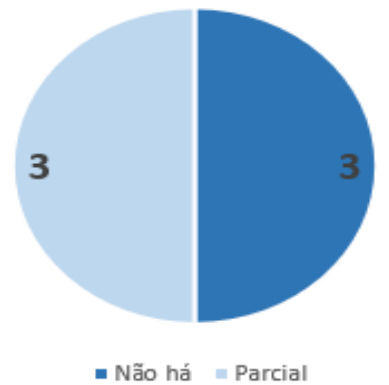

A classificação é feita sob a óptica do espectador, considerando possíveis perdas quanto à narrativa e à construção das personagens nas obras. Não há perdas em casos em que a legenda é responsável pela comunicação de maneira satisfatória das principais características das personagens nas cenas selecionadas. Há perdas parciais nas quais, dada alguma decisão tradutória, a construção das personagens e da cena analisada é prejudicada pela redução ou 
omissão de itens verbais. Nesses casos, entretanto, a mostração fílmica se responsabiliza por suprir as possíveis lacunas geradas na compreensão da obra, através de seus canais visuais e sonoros, dada a redundância dos canais fílmicos (DÍAZ CINTAS; REMAEL, 2014). Por fim, são consideradas perdas severas os casos em que, devido à tradução e ao caráter majoritariamente verbal de algum aspecto constitutivo das personagens, como um jogo de palavras perdido na tradução, a linguagem cinematográfica não permite o preenchimento de tal lacuna.

É perceptível como, na maioria dos casos, as técnicas de redução e omissão aplicadas pelos legendadores de ambas as obras não resultam em perdas significativas para o espectador, que é capaz, através da leitura semiótica da linguagem cinematográfica, de compreender a narrativa e a construção das personagens. Gestos, expressões faciais, tons de voz e a construção diretorial da obra (cortes, trilha sonora, enquadramento etc.), enxergada também como linguagem (GAUDREAULT; JOST, 2009), responsabilizam-se por garantir que o espectador compreenda a narrativa em sua totalidade.

As expressões faciais mostraram-se fundamentais na construção narrativa das obras, 224 sobretudo do filme Magnólia. A presença de closes faciais, que demandam a atenção do espectador em direção ao rosto das personagens (KRESS; VAN LEEUWEN, 2006) e o aproximam de suas subjetividades narrativas (GAUDREAULT; JOST, 2009) revelam, em um primeiro momento, a intenção diretorial de destaque às expressões, responsáveis, em diversas cenas, pela principal caracterização emocional das personagens, como exposto durante a análise. A utilização do processamento digital de imagens para identificação e quantificação emocional de expressões faciais por meio do software da Affectiva revelou-se desafiadora, tendo em vista seu caráter inovador e as restrições impostas às cenas analisadas. Construíramse, ao fim da análise, os Gráficos 3 e 4, considerando os dados obtidos através da utilização da ferramenta EMOVIE.

Gráficos 3 e 4 - Leituras geradas pelo processamento digital
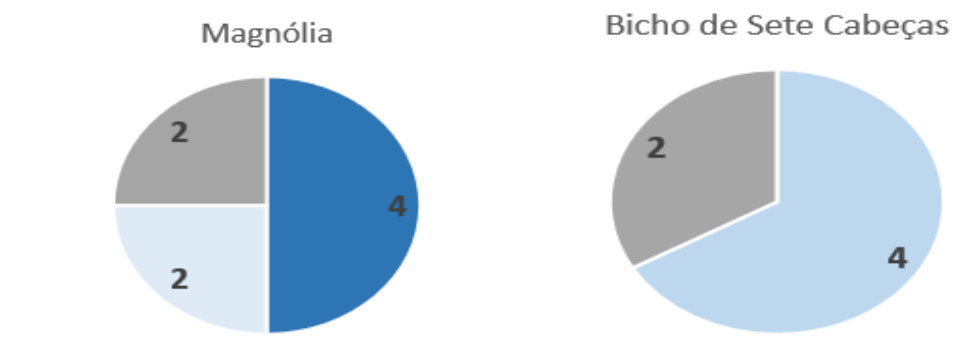

- Satisfatória Parcialmente Satisfatória = Insatisfatóría

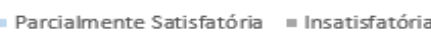

Elaboração: os autores 
São consideradas leituras satisfatórias aquelas em que se afinam as emoções apontadas pelo software e a interpretação dos pesquisadores (enquanto espectadores humanos) em relação ao teor emocional das cenas analisadas. Quando há captura facial e quantificação emocional, mas essas se distanciam parcialmente da leitura dos pesquisadores (seja pela neutralidade percebida pelo software, mas não pelos pesquisadores, ou pela inserção de uma emoção reconhecida como "intrusa"), as cenas foram classificadas como parcialmente satisfatórias. Por fim, as cenas consideradas insatisfatórias são aquelas nas quais o software, por algum motivo, não foi capaz de apontar dados para as personagens em cena ou os dados apontados foram descartados como irrelevantes, dada a baixa quantificação emocional.

Percebemos uma grande diferença entre as cenas analisadas de Magnólia e de Bicho de Sete Cabeças. A produção estadunidense revelou-se fecunda para a análise, graças à predominância de cenas filmadas com câmera estática e closes faciais, demonstrando maior afinidade entre as leituras do software e a dos pesquisadores. Bicho de Sete Cabeças, por sua vez, revelou-se mais resistente à análise, devido à baixa presença de closes faciais e à reduzida qualidade de produção de vídeo da obra.

A aplicação do processamento digital de imagens às narrativas fílmicas, observadas também sob o ponto de vista da legendagem, configura-se como campo transdisciplinar de caráter inovador, fomentando em sua aplicação uma série de novas questões quanto à utilização dos softwares e sua aplicabilidade real no processo tradutório de legendagem. Nesse sentido, a presente pesquisa esforça-se por apresentar um panorama das questões surgidas durante o processo de análise e as possíveis respostas para os problemas identificados, das quais emergem novas possibilidades de utilização do processamento digital e dos softwares descritos. A continuada exploração desse campo torna-se imprescindível, dado o pontapé inicial, para que se descubram novas e melhores formas de utilização das novas tecnologias a serviço do tradutor e do espectador.

\section{REFERÊNCIAS}

ANDRADE, Nara Cortês; ABREU, Neander Silva; DURAN, Victor Riccio; VELOSO, Tainã Jesus; MOREIRA, Narena Alencar. Reconhecimento de expressões faciais de emoções: padronização de imagens do teste de conhecimento emocional. Psico, Porto Alegre, PUCRS, v. 44, n. 3, p. 382-390, 2013. Disponível em:

http://revistaseletronicas.pucrs.br/ojs/index.php/revistapsico/article/view/15825 Acesso em: 15 dez. 2019. 
AFFECTIVA Emotion as a Service. [S.l.]: Affectiva, 2018. Disponível em: https://www.affectiva.com/ Acesso em: 15 dez. 2019.

BANDICAM Screen Recorder. Version 4.1.4.1413. [S.l.]: Bandicam Company, 2018.

Disponível em: https://www.bandicam.com/downloads/. Acesso em: 15 dez. 2019.

BANDICUT Video Cutter. Version v3.1.2.441. [S.l.]: Bandicam Company, 2018. Disponível em: https://www.bandicam.com/bandicut-video-cutter/download/. Acesso em: 15 dez. 2019.

BICHO de Sete Cabeças. Direção: Laís Bodanzky. Produção: Sara Silveira, Caio Gullane, Fabiano Gullane, Luiz Bolognesi, Marco Müller. Brasil: RioFilme, 2001.

DEMOS, Bibiane. Reconhecimento de expressões faciais em indivíduos com doença de Parkinson. 2011. Dissertação (Mestrado em Psicologia) - Instituto de Psicologia, Universidade de Brasília, Brasília. Disponível em:

https://repositorio.unb.br/bitstream/10482/8776/3/2011_BibianeDemos.pdf. Acesso em: 15 dez. 2019.

DÍAZ CINTAS, Jorge; REMAEL, Aline. Audiovisual translation: Subtitling. UK: Routledge, 2014. doi: https://doi.org/10.4324/9781315759678

EKMAN, Paul; FRIESEN, Wallace V. Unmasking the face: A guide to recognizing emotions from facial clues. United States: Malor Books, 2003.

GAUDREAULT, Andre; JOST, François. A narrativa cinematográfica. Brasília: Editora Universidade de Brasília, 2009.

LEÃO, Leonardo Panta; BEZERRA, Jonas Santos; MATOS, Leonardo Nogueira; NUNES, Maria Augusta Silveira Netto. Detecção de expressões faciais: uma abordagem baseada em análise do fluxo óptico. Revista GEINTEC, São Cristovão, v. 2, n. 5, p. 472-489, 2012. Disponível em: http://www.revistageintec.net/index.php/revista/article/view/73 Acesso em: 15 dez. 2019. https://doi.org/10.7198/S2237-0722201200050005

OPENSUBTITLES.org. Bicho de Sete Cabeças Legendas Inglês. Opensubtitles.org, 2000. Disponível em: https://www.opensubtitles.org/pb/subtitles/4455639/bicho-de-sete-cabecas-en. Acesso em: 15 dez. 2019.

MAGNÓLIA. Direção: Paul Thomas Anderson. Produção: Paul Thomas Anderson e JoAnne Sellar. Estados Unidos: New Line Cinema, 1999.

PEIRCE, Charles Sanders. Semiótica. São Paulo: Perspectiva, 2010.

PLAZA, Júlio. Tradução Intersemiótica. São Paulo: Perspectiva, 2003.

SANTAELLA, Lúcia. O que é Semiótica. São Paulo: Brasiliense, 1983.

SILVA, Andresso; BRANCO, Sinara de Oliveira. Desenvolvimento de software para análise de expressões faciais e emocionais humanas a partir da tradução intersemiótica e 
processamento digital de imagens. Relatório PIBITI (CNPq). Universidade Federal de Campina Grande, 2018.

SOUSA, Ailton Lopes de; COSTA, Saulo William da Silva; PIRES, Yomara Pinheiro; ARAÚJO, Fabíola. Reconhecimento de expressões faciais e emocionais como método avaliativo de aplicações computacionais. In: ENCONTRO REGIONAL DE COMPUTAÇÃO E SISTEMAS DE INFORMAÇÃO, 2016, Manaus. Anais... Curitiba: 2016a. p. 178-187.

SOUSA, Ailton Lopes de; COSTA, Saulo William da Silva; PIRES, Yomara Pinheiro; ARAÚJO, Fabíola. FOURFACE: Uma ferramenta de reconhecimento de expressões faciais. In: EATI - ENCONTRO ANUAL DE TECNOLOGIA DA INFORMAÇÃO, Ano 6, n. 1, 2016, Frederico Westphalen. Anais... Frederico Westphalen: 2016b. p. 185-192.

\footnotetext{
${ }^{1}$ Original: "multisignal, multimessage system”.

${ }^{2}$ Original: "a translation practice that consists of presenting a written text, generally on the lower part of the screen, that endeavours to recount the original dialogue of the speakers, as well as the discursive elements that appear in the image (letters, inserts, graffiti, inscriptions, placards, and the like) and the information that is contained on the soundtrack (songs, voices off)".

${ }^{3}$ Empresa de tecnologia de quantificação emocional localizada em Boston, Massachusetts, Estados Unidos. Mais informações disponíveis no site da empresa: www.affectiva.com.

${ }^{4}$ Autor anônimo. Disponível em: https://www.opensubtitles.org/pb/subtitles/4455639/bicho-de-sete-cabecas-en. Acesso em: 19 dez. 2019.

${ }^{5}$ Orientado pela Profa. Dra. Sinara de Oliveira Branco (UAL/CH/UFCG) sob supervisão e colaboração da Profa. Dra. Luciana Ribeiro Veloso (DEE/CEEI/UFCG).

${ }^{6}$ Original: "Intersemiotic cohesion in subtitling refers to the way it connects language directly to the soundtrack and to images on screen, making use of the information they supply to create a coherent linguistic-visual whole".
}

\section{NOTA DOS AUTORES}

Pedro Henrique de Paiva GAUDENCIO - Graduando em Letras - Língua Inglesa pela Universidade Federal de Campina Grande (UFCG). Universidade Federal de Campina Grande, Centro de Humanidades, Unidade Acadêmica de Letras. Campina Grande, Paraíba, Brasil.

ORCID: http://orcid.org/0000-0002-2260-7546

Currículo acadêmico: http://lattes.cnpq.br/3282000334525951

E-mail: pedrohpgaudencio@gmail.com

Sinara de Oliveira BRANCO - Doutora (2007) e Mestre (2002) em Inglês: Estudos Linguísticos e Literários pela Universidade Federal de Santa Catarina. Graduada em Letras (1933) pela Universidade Federal da Paraíba. Professora associada à Universidade Federal de Campina Grande. Universidade Federal de Campina Grande, Centro de Humanidades, Unidade Acadêmica de Letras. Campina Grande, Paraíba, Brasil.

ORCID: https://orcid.org/0000-0003-2739-2254

Currículo acadêmico: http://lattes.cnpq.br/6023441911258549

E-mail: sinarabranco@gmail.com

Luciana Ribeiro VELOSO - Doutora em Engenharia Elétrica (2009) pela Universidade Federal de Campina Grande. Mestre em Engenharia Elétrica (1998) pela Universidade Federal da Paraíba. Graduada em Engenharia Elétrica pela Universidade Federal da Paraíba (1995). Professora da Universidade Federal de Campina Grande. Universidade Federal de Campina Grande, Centro de Engenharia Elétrica e Informática, Departamento de Engenharia Elétrica. Campina Grande, Paraíba, Brasil.

ORCID: https://orcid.org/0000-0001-7564-1038

Currículo acadêmico: http://lattes.cnpq.br/2498050002491677

E-mail: luciana.veloso@dee.ufcg.edu.br 